\title{
Analisis Kerajinan Boneka Dari Limbah Karung Goni Dan Kain PercaDitinjau DariGesture
}

\section{Analysis Of Doll Craft Waste From Goni Sack Waste And Clothing From Gesture}

\author{
Nia Lolo Sabrina Nasution* \& Sri Wiratma \\ Program Studi Pendidikan Seni Rupa, Jurusan Seni Rupa, Fakultas Bahasa dan Seni, \\ Universitas Negeri Medan, Indonesia
}

Diterima: 03 Oktober 2020; Direview: 03 Oktober 2020; Disetujui: 18 Oktober 2020

Email: nialolo16@gmail.com

\begin{abstract}
Abstrak
Penelitian ini bertujuan untuk mendeskripsikan gesture pada boneka berbahan limbah karung goni dan kain perca sebagai kerajinan.Teknik pengumpulan data pada penelitian ini adalah observasi, dokumentasi dan wawancara.Jumlah populasi penelitian 15 boneka yang ada di pengrajin boneka.Teknik pengambilan sampel peneliti ini adalah total sampling, yaitu diambil dari keseluruhan populasi yang berjumlah 15 kerajinan boneka dari limbah karung goni dan kain perca.Hasil penelitian ini menunjukan bahwa terbatasnya variasi dalam penerapan ekspresi wajah pada produk boneka.Gesture pada boneka menonjolkan bentuk yang rapi dan kokoh tetapi memiliki sifat yang elastis sehingga pencapaian gesture pada boneka sudah menunjukan karakter pada aktivitas manusia.Selain bentuk yang unik serta warna yang dihasilkan dari kain perca menjadikan center pointatau daya tarik yang bagus untuk menarik perhatian konsumen.Selanjutnya didalam pembuatan boneka dari limbah karung goni dan kain perca memiliki keunikan dalam penciptaanya yang digunakan sebagai acuan membuat suatu produk boneka, yaitu memiliki ciri khas tertentu, contohnya pada hasil boneka ini memiliki ciri khas yang bertema aktivitas pada manusia.
\end{abstract}

Kata Kunci: Gesture, Kerajinan Boneka, Limbah Karung Goni, Kain Perca

\begin{abstract}
This study aims to describe the cues on dolls made of jute sack waste and patchwork as crafts. The data study techniques in this study were observation, documentation and interviews. The total population of the study was 15 dolls in the doll craftsmen. The sampling technique of this researcher was total sampling, which was taken from the total population who drew doll crafts from gunny sacks and patchwork. The results showed that there was limited variation in facial expressions in doll products. Gestures on dolls are neat and sturdy but have elastic properties so that the movements of the dolls show character in the activity. In addition to the unique shape and color produced from the patchwork, it is a center point or a great attraction to attract consumers' attention. Furthermore, in making dolls from jute sack waste and patchwork, it is unique in its creation which is used as a reference for making a doll product, which has certain characteristics, for example the results of this doll have characteristics related to human activity.
\end{abstract}

Keywords: Gestures, Doll Crafts, Jute Sack Waste, Patchwork

How to Cite: Nasution, N.L.S, \& Wiratma, S. (2020). Analisis Kerajinan Boneka Dari Limbah Karung Goni Dan Kain Perca Ditinjau Dari Gesture. Journal of Education, Humaniora and Social Sciences (JEHSS). 3 (2): 644-649.

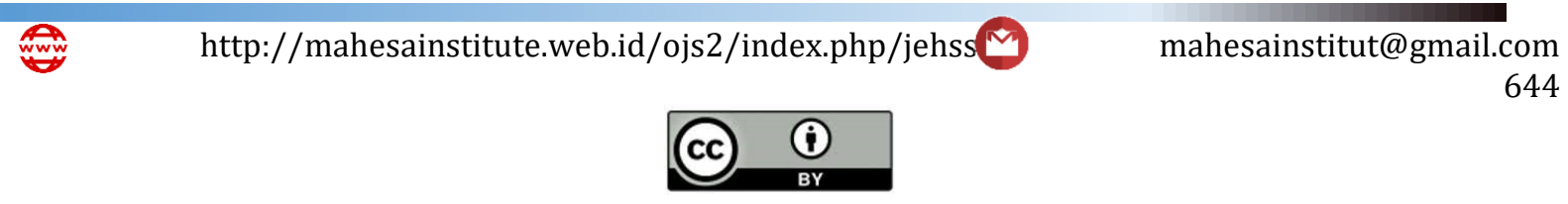




\section{PENDAHULUAN}

Seni kerajinan merupakan hasil karya manusia yang memiliki nilai fungsional.Kerajinan merupakan salah satu bagian dari seni rupa yang sudah ada sejak lama.Saat ini kerajinan sudah sangat berkembang sehingga munculnya kerajinan moderen. Di Indonesia sangat banyak pengrajin yang menghasilkan karya seni kerajinan dan industri-industri kreatif yang memanfaatkan limbah-limbah sebagai bahan baku kemudian diolah sedemikian rupa sehingga membentuk sebuah produk atau karya kreatif dan bernilai ekonomis.

Salah satu kerajinan yang paling digemari orang adalah boneka.Hal ini dikarenakan banyak yang menjadikan boneka sebagai sebuah hadiah bagi orang-orang terdekat mereka, karena sifatnya yang "luwes".Boneka sangat mudah sekali ditemukan atau diperoleh di toko-toko maupun dipusat perbelanjaan lainnya.Bentuk serta mimik wajah boneka yang variatif dan selalu berkembang setiap waktu membuat bisnis ini cukup menjanjikan. Belakangan ini, banyak orang yang mencari boneka sesuai karakter seseorang yang mereka inginkan atau sesuai dengan gambaran ide mereka guna menciptakan sebuah boneka yang "spesial" atau "berbeda" dengan milik kebanyakan orang.

Dalam pembuatan kerajinan boneka figure dari limbah goni dan kain perca, warna yang dihadirkan oleh pengrajin adalah warna dasar dari limbah goni tersebut, perpaduan kain perca untuk menambah keindahan warna dan semakin mendukung kegiatan ditampilkan boneka. Adapun warna lain yang dihasilkan pada bentuk boneka berupa warna dalam properti pendukungnya seperti boneka figure sedang bermain gitar maka gitar tersebut yang diberi warna, ada juga boneka figure membawa jamu yang diberi warna sehingga menyerupai bentuk aslinya. Bentuk boneka yang diciptakan oleh pengrajin adalah bentuk-bentuk seperti bermain musik, aktifitas diwarung kopi hingga seorang petani dengan cangkulnya dan masih banyak lagi aktivitas boneka yang dibuatnya.

Dikutip dari Narjoko (2015) menjelaskan "Jika dilihat dari padanan kata "Kerajinan" dalam bahasa Inggris, maka akan kita temukan kata "craft". Berasal dari bahasa Inggris kuno yang merupakan serapan dari bahasa Jerman kata ini memiliki arti kekuasaan, kekuatan fisik, dan keahlian, dalam bahasa Belanda yaitu "kacht" dan juga bahasa Swedia "Kraft" yang memiliki arti "kekuatan". Kata (Kerajinan berasal dari kata "rajin" yang berarti suka bekerja, gentol, dan sungguh - sungguh dalam bekerja ada juga istilah yang sering dipakai untuk kata kerajinan, yaitu kriya yang berarti pekerjaan (kerajinan) tangan (Rusdi et al., 2020; Utami et al., 2020). Selanjutnya Rambe (2012) Kerajinan merupakan kegiatan kreatif yang berkaitan dengan kreasi, produksi dan distribusi produk yang dibuat dan dihasilkan oleh tenaga pengrajin yang berawal dari desain awal sampai dengan proses penyelesaian produknya, yang memberikan penekanan pada penciptaan benda-benda fungsional dari karya kerajinan, karya teknologi sederhana, yang bertumpu pada keterampilan tangan. Berdasarkan pendapat di atas kerajinan adalah suatu keterampilan seseorang menggunakan tangan ataupun mesin untuk menciptakan suatu karya seni.

Menurut Tiara (2002) menyatakan "boneka merupakan mainan yang sangat di gemari oleh segala usia baik anak-anak, remaja, ataupun orang dewasa. Boneka bukan hanya sekedar mainan melainkan juga dapat berfungsi sebagai teman setia.Boneka merupakan suatu kebahagiaan tersendiri. Boneka dengan berbagai ekspresi yang lucu, lembut, tertawa, gembira, memiliki karakter tersendiri yang dapat menciptakan kepuasan dan kegembiraan tersendiir bagi yang melihatnya". Berdasarkan pendapat di atas maka dapat disimpulkan boneka tidak hanya menjadi mainan tetapi juga bisa menjadi hiasan rumah.

Menurut Saragih (2019) "Dikraf merupakan salah satu usaha kerajinan yang bergerak dalam pembuatan miniatur, lukisan dari bahan serbuk kayu, lampu hias serta boneka yang terbuat dari bahan limbah karung goni. Dengan memanfaatkan bahan limbah, pengrajin Dikraf mampu menyulap bahan tersebut menjadi sebuah kerajinan yang unik dan memiliki nilai jual.Salah satu kerajinan dikraf yaitu boneka yang terbuat dari bahan limbah karung goni.

Boneka tersebut merupakan boneka figure yang memiliki keunikan tersendiri karena terbuat dari bahan limbah karung goni. Boneka tersebut berukuran kecil dan memiliki unsur 
pendukung yang juga terbuat dari bahan limbah lainnya yang dipadukan sehingga menimbulkan kesan cerita didalamnya yang bisa kita sebut sebagai kerajinan souvenir diorama. Menurut Purwanthari (2017) "Kain perca merupakan sisa kain dari proses penjahitan. Sepintas kain sisa ini adalah kain yang tidak memiliki manfaat, tetapi sebenarnya sisa kain ini dapat dimanfaatkan menjadi suatu produk yang berguna.

Menurut Suryani, dkk (2016) menyatakan "Jenis kain perca yang dihasilkan oleh industri pakaian jadi bermacam-macam tergantung dari produk yang dibuat oleh industri tersebut. Adapun jenis kain perca yaitu kain satin polos dan bermotif, kain katun polos dan bermotif, kain tenunan polos dan bermotif, kain renda (lace), kain sifon polos dan bermotif, kain kaos, kain pelapis terdiri atas kain asahi dan abutai dan sebagainya. Tahap pertama dalam pembuatan produk kerajian kain perca yaitu tahap pemilahan.Tahap pemilahan kain perca berdasarkan jenis kain dan motif kain dari tempat penumpukan kain perca.Bahan yang kecil-kecil dipisahkan sehingga memudahkan untuk mencari bahan membuat produk kerajinan yang lebih besar. Berdasarkan beberapa pendapat di atas maka dapat disimpulkan karung goni dan kain perca merupakan salah satu kerajinan yang tergolong limbah yang dapat dimanfaatkan kembali menjadi karya seni yang memiliki nilai jual yang tinggi.

Menurut Habibah (2018) menjelaskan bahwa "Gesture adalah suatu bentuk komunikasi non verbal dengan aksi tubuh terlihat mengkomunikasikan pesan-pesan tertentu,baik sebagai pengganti wicara atau bersamaan dan pararel dengan kata-kata. Menurut bahasa gesture berarti gerak tangan. Pengertian Gesture secara ilmiah adalah gerakan tubuh lainya untuk ,menekankan atau membantu mengekspresikan pikiran atau perasaan seorang dalam berinteraksi dan berkomunikasi. Focus yang diambil yaitu gesture yang terjadi bersama ucapan. Berdasarkan pendapat David Mc niell Gerakan yang dimaksud adalah gerakan tangan dan lengan yang kita lihat saat orang berbicara. Gesture adalah ciptaan spontan masing-masing pembicara yang bersifat unik dan pribadi. Berdasarkan beberapa pendapat di atas maka dapat disimpulkan gesture merupakan komunikasi non verbal dengan aksi gerakan tubuh yang terlihat mengkomunikasikan pesan-pesan tertentu.

Ada beberapa jenis pesan non verbal yaitu : Pesan Kinesik merupakan pesan yang menggunakan gerakan tubuh yang berarti (Putra 2013), Pesan Gestural Menujukan gerakan sebaga anggota badan seperti mata dan tangan untuk mengkomunikasikan berbagai makna. Pesan ini berfungsi untuk mengungkapkan: mendorong atau membatasi, menyesuaikan atau mempertentangkan, responsif positif atau negative, memperhatikan atau tidak memperhatikan, melancarkan atau tidak reseptif, menyetujui atau menolak (Putra 2013), Pesan postural Berkaitan dengan keseluruhan anggota badan. Tiga makna dapat disampaikan postur adalah sebagai berikut: Immediacy merupakan ungkap kesukaan atau ketidak sukaan terhadap individu yang lain. Postur yang condong kearah lawan bicara menunjukan kesukaan atau ketidaksukaan. Power mengungkapkan status yang tinggi pada komunikator. Responsivenss individu mengkomunikasikanya bila ia bereaksi secara emosiona pada lingkunganya, baik positif maupun negative (Putra 2013). Pesan Artifaktual Pesan ini diungkapkan melalui penampilan seperti pakaian, kosmetik, dan lain-lain. Umumnya pakaian dipergunakan untuk menyampaikan identitas yang berarti menunjukan kepada orang lain bagaimana kita dan bagaimana memperlakukan kita (Putra 2013).

Manfaat mempelajari gesture menyelamatkan hubungan dan menghindari kesalah pahaman. Dengan memahami bahasa tubuh, bukan hanya hubungan yang sudah terjalin lama akan dapat diselamatkan, tetapi juga dalam beberapa detik, hubungan itu bisa mennjadi hubungan sehidup semati atau seproyek sepenanggungan (Ayoga 2013). Dapat menyelamatkan diri dari bahaya, termasuk lepas dari manipulasi seseorang (Ayoga 2013). Mendapatkan rezeki dan kebahagiaan. Dimana dalam seni bernegoisasi, bahasa tubuh memainkan peran yang sangat penting (Ayoga 2013). Dalam buku Ayoga (2013) Jane Templeton mengemukakan, jika mata seorang pembeli terlihat putus asa dan wajahnya berpaling, berarti anda diminta untuk diam. Sebaliknya, jika mulutnya tenang, tidak memperlihatkan senyuman dingin dan dagunya agak maju, kemungkinan dia sedang memikirkan penawaran anda. Bahasa tubuh merupakan suatu 646 http://mahesainstitute.web.id/ojs2/index.php/jehss

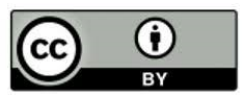


kesatuan yang menjadi bagian tak terpisahkan sejak anda mulai bangun tidur sampai mau tidur lagi, bahkan ketika sedang tidur. Cara mempelajari gesture menurut Ayoga (2013) Pemahaman tentang gestureatau komunikasi nonverbal, pertama kali ditulis secara serius oleh carles Darwin pada 1872, dalam buku The expression of emoticon in mman and animals. Maasa itu masih amat jarang dilakukansebuah penelitian tentang bahasa tubuh.Baru pada 1960-an, hasil-hasil penelitian mulai gencar, dan G. F. Michel. Dan puncaknya, Julius fat menerbitkan buku pada 1970 tentang bahasa tubuh yang merupakan rangkuman hasil penelitian beberapa ahli komunikasi nonverbal kala itu. Sejak saat itulah, penelitian tentang body language dapat berkembang pesat.

Penelitian ini dimaksudkan untuk meneliti gesture dari boneka figure manusia dari limbah karung goni. Jadi penelitian ini bermanfaat untuk pendidikan seni rupa karena dapat menambah pengetahuan tentang kerajinan yang terbuat dari limbah karung goni dan kain perca serta dapat mempelajari gesture boneka agardapat digunakan oleh setiap orang peminatnya.Maka dari itu peneliti ingin melakukan penelitian dengan judul“Analisis Kerajinan Boneka Dari Limbah Karung Goni dan Kain Perca ditinjau dari Gesture".

\section{METODE PENELITIAN}

Metode penelitian yang digunakan yaitu metode penelitian deskriptif kualitatif. Teknik pengumpulan data yang digunakan observasi, dokumentasi, dan wawancara. Instrumen peneltian yang digunakan yaitu catatan report, kamera, laptop, buku pedoman, wawancara dan daftar pertanyaan. Teknik analisis data yang digunakan yaitu deskriptif kualitatif. Pengertian analisis menurut Kamus Besar Bahasa Indonesia (2002) adalah penguraian suatu pokok atas berbagai bagiannya dan penelaahan bagian itu sendiri serta hubungan antara bagian untuk memperoleh pengertian yang tepat dan pemahaman arti keseluruhan.

Berdasarkan pendapat di atas maka dapat disimpulkan bahwa analisis adalah proses kerja atau cara berfikir yang mengatur tahapan pekerjaan sebelum riset, didokumentasikan sehingga penelitian dapat diinformasikan kepada orang lain yang akan ditinjau pada produk kerajinan boneka berbahan limbah karung goni dan kain perca di jalan Danau singkarak Gg. Madrasah Medan Helvetia ditinjau dari Gesture. Menurut Sugiyono (2016) Metode penelitian adalah cara ilmiah untuk mendapatkan data dengan tujuan dan kegunaan tertentu. Metode deskriptif dapat disimpulkan sebagai sebuah metode yang bertujuan untuk melukiskan atau menggambarkan keadaan di lapangan secara sistematis dengan fakta-fakta yang tepat serta data yang saling berhubungan, dimana bukan hanya mencari kebenaran yang mutlak tetapi pada hakekatnya mencari pemahaman observasi.

\section{HASIL DAN PEMBAHASAN}

Berdasarkan hasil pengamatan peneliti dan analisis karya kerajinan boneka berbahan limbah karung goni dan kain perca di jalan Danau singkarak Gg. Madrasah Medan Helvetia yang dinilai berdasarkan Gesture.

\section{1) Boneka Sedang Membawa Alat Tani}
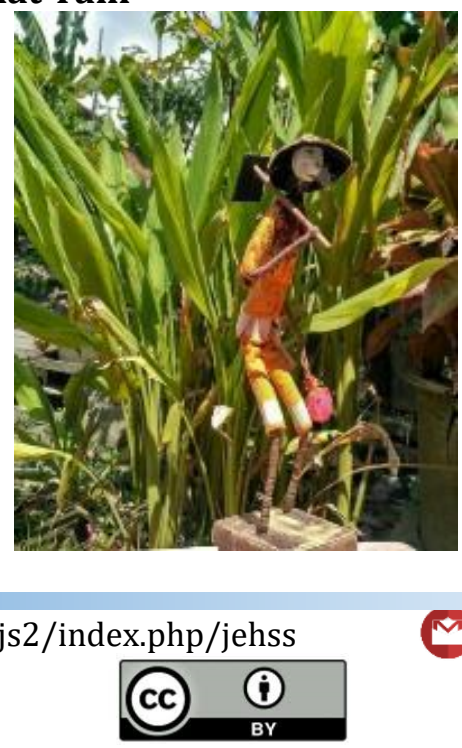


\section{Gambar 1 Boneka sedang membawa alat tani}

(Foto: nia lolo Sabrina nst)

Hasil karya boneka yang sedang membawa alat tani dikategorikan baik, karena Ekspresi yang di tunjukan boneka kurang menunjukan emosional karakter manusia. Gesturepada boneka ini secara keseluruhan baik, karena bentuk tubuh boneka terlihat luwes. Gesture tangan dan kaki pada boneka ini terlihat rapih dan elastis. Kain perca pada boneka mendukung visualisasi pada boneka, dikarenakan kontras warna yang menonjol pada kain perca sehingga dapat dirasakan dengan kepekaan estetis.

\section{2) Boneka Berjualan Ketoprak}

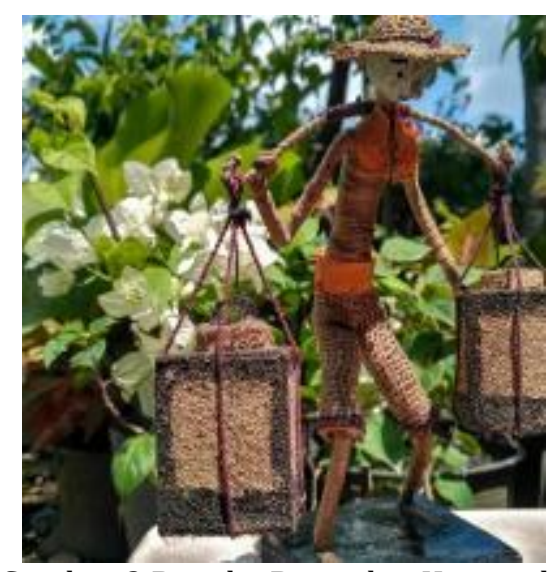

Gambar 2 Boneka Berjualan Ketoprak

(Foto: Nia Lolo Sabrina Nasution)

Hasil karya boneka yang sedang berjualan ketoprak dikategorikan sangat baik karena adanya keselarasan antara objek dan warnanya terlihat harmonis. Ekspresi pada boneka sesuai dengan aktivitas yang dilakukan pada boneka, adanya elemen pembantu pada boneka seperti grobak atau kain perca sehingga karya ini terlihat menonjol dan unik.Gesture pada boneka dikategorikan sangat baik karena tangan dan kaki pada boneka seimbang sehingga boneka terlihat nyata sesuai dengan aktivitas yang boneka tampilkan.

\section{3) Boneka Sedang Membawa Kayu}

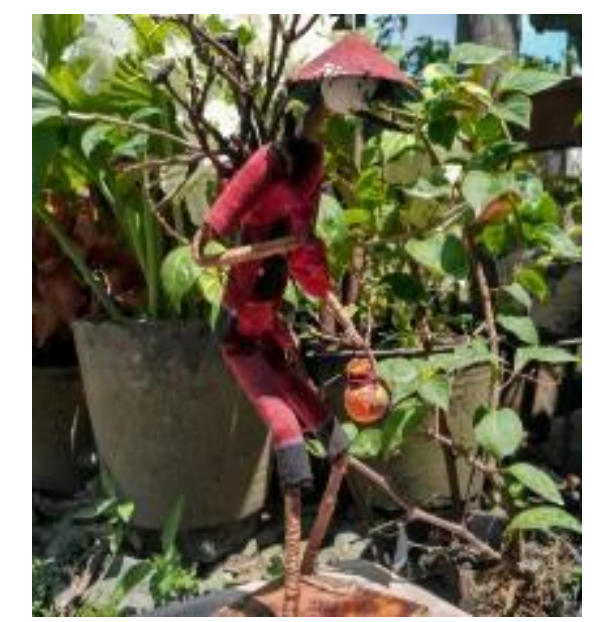

Gambar 3 Boneka Sedang Membawa Kayu

(Foto: Nia Lolo Sabrina Nst)

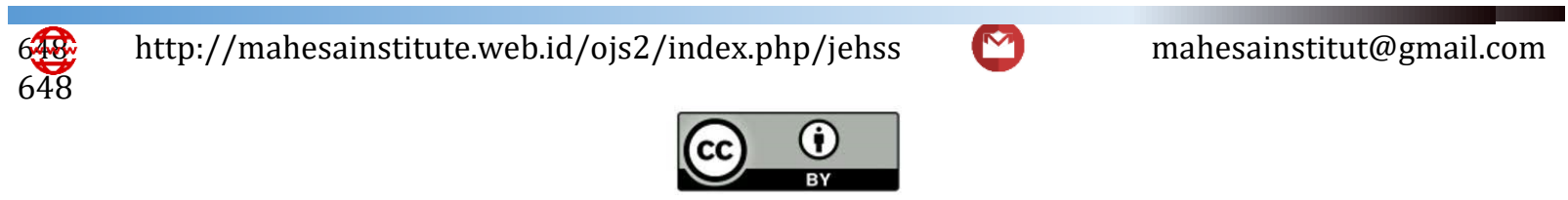


Hasil karya boneka sedang membawa kayu dikategorikan sangat baik. Ekspresi pada boneka masih terlihat kaku tetapi penempatan mata, hidung, dan mulut sudah sesuai dengan porsi pada wajah, adanya elemen pendukung pada boneka menjadikan boneka terlihat menarik.Gesture pada boneka dikategorikan baik karena bagian tubuh pada boneka di buat dengan kokoh dan balutan pada benang karung goni terlihat rapi dan ketat, selanjutnya pada bagian tangan dan kaki pada boneka terlihat luwes sehingga mudah untuk di bentuk.Penambahan aksesoris pada boneka seperti kain perca dan ranting pohon dapat membuat boneka terlihat unik.

\section{SIMPULAN}

Gesture pada kerajinan boneka berbahan limbah karung goni dan kain perca secara keseluruhan dinyatakan baik, namun pada sebagian karya masih terdapat beberapa kekurangan pada gesture.Adapun kekurangan dari gestureyaitu ekspresi wajah pada boneka masih terlihat kaku, gesture boneka kurang menunjukan keluwesan. Gesturepada sebagian karya boneka sudah menggambarkan gerakan atau aktivitas karakter manusia yang di di tampilkan dalam bentuk sebuah boneka. Pencapaian gesture pada boneka keseluruhannya sudah baik, pembalutan benang karung goni pada boneka sudah rapi dan kokoh, adapun 2 karya boneka yang dikategorikan sangat baik, 1 karya boneka yang dikategorikan baik.

\section{DAFTAR PUSTAKA}

Amda, K. (2016). Membaca Ekspresi Wajah. Depok: Huta Publisher

Ayoga, B. (2013).2 Menit Membaca Pikiran Orang. Yogyakarta: Penerbit Buku Pintar

KBBI. (2007). KamusBesarBahasa Indonesia. Jakarta: Balai Pustaka

Narjoko, T. (2015). Rencana Pengembangan Kerajinan Nasional 2015-2019. Jakarta: PT Republik Solusi

Purwanthari, A, (2017).Pelatihan Pembuatan Bross Dengan Bahan Dasar Kain Perca Desa Cangkringan Kecamatan Prambon Kabupaten Sidoarjo. Abadimas Adi Buana Vol. 01, No. 01

Putra, D.E. (2015). Reading People's Mind Through Body Language. Jakarta: Guepedia

Putra, E. (2013). Rahasia Bahasa Tubuh. Jakarta: Penerbit Titik Media

Rambe, A. (2012). Diktat Dasar Kerajinan. Medan: Universitas Negeri Medan.

Saragih, L.A. (2019). Analisis Kerajinan Souvenir Diorama Berbahan Limbah Pada Pengrajin Dikraf Berdasarkan Prinsip-Prinsip Desain.Gorga Jurnal Seni Rupa. 8 (01) 273-278

Sugiyono. (2016). Metode Penelitian Kuantitatif, Kualitatif dan R\&D. Bandung: Penerbit Alfabeta

Tiara, Aksa. (2002). Sweety Dolls Boneka dari Kain yang Lucu dengan Berbagai Karakter. Gramedia

Rusdi, L., Soeprayogi, H., \& Mesra, M. (2020). Kerajinan Anyaman Bambu Di Sanggar Kreatif "Bunga Matahari" Kelurahan Rambung Barat Kecamatan Binjai Selatan. Journal of Education, Humaniora and Social Sciences (JEHSS), 3(1), 133-140. doi:https://doi.org/10.34007/jehss.v3i1.216

Utami, A., Soeprayogi, H., \& Azis, A. (2020). Pembuatan Kerajinan Bunga Berbahan Kulit Jagung Ditinjau dari Prinsip-prinsip Seni Rupa dan Kerajinan. Journal of Education, Humaniora and Social Sciences (JEHSS), 3(1), 260-264. doi:https://doi.org/10.34007/jehss.v3i1.282 